\title{
Response of Local Orange Grafted to the Date of Grafting, Chemical, Organic and Bio-fertilizers
}

\author{
Ayad Hani Ismail Al-Allaf and Nameer Najib Fadel Hadeed
}

Department of Horticulture and Garden Engineering, College of Agriculture and Forestry, University of Mosul, Iraq

Received: 30 Sept. 2019 / Accepted 17 Nov. 2019 / Publication date: 25 June 2020

\begin{abstract}
This study was carried out in the wooden canopy belonging to the Department of Horticulture and Garden Engineering Faculty of Agriculture "Mosal Univ" during the growing season 2018 in order to demonstrate the importance of the effect of two dates for spring grafting $\left(2^{\text {nd }}\right.$ and $17^{\text {th }}$ April) and fertilization of local oranges seedlings grafted on bitter orange rootstock to compound fertilizer (NPK) at $30 \mathrm{~g} /$ seedling, organic liquid fertilizer "Nutrigreen" at $6 \mathrm{ml} / \mathrm{L}$ and using three types of biofertilizers such as Biogen at 3 and $6 \mathrm{~g} /$ seedling, Potasiomag at 5 and $10 \mathrm{~g} /$ seedling and Fulzyme at 1 $\mathrm{g} /$ seedling as a nutrient elements. The experiment was designed using of the complete randomized block design (RCBD) with three replicates and five seedlings per experimental unit. Averages were compared using Dunkin test at 5\% level.The results showed that the first date of grafting ( $2^{\text {nd }}$ April) affected significantly the characteristics studied, especially the percentage of successful grafts, the number of leaves and the leaf content of nitrogen. The bio-fertilization treatments with Biogen and Potasiomag were significantly superior to other fertilizer treatments, especially the control treatment by the percentage of successful grafts, the number of leaves and the leaf content of nitrogen phosphorous and potassium.
\end{abstract}

Keywords: Bitter orange, Local orange, grafting, Organic fertilization, Bio-fertilization, NPK

\section{Introduction}

Citrus reproduces often by grafting seed seedlings of various rootstocks, the selection of which is subject to the degree of their suitability to environmental conditions related to soil, climate and pathogens, as well as the degree of their compatibility with the taste in the grafting process (Khan 2007), and shield grafting or the so-called (T-grafting) is considered the method Common in the propagation of commercial citrus fruits on the seed rootstocks of citrus fruits in Iraq, as the desired varieties are fed to the seed and vegetable rootstocks of some types and genera of citrus fruits at different dates, either in the spring during (March and April) or in the autumn (September and October) (Chaudhary, 2000).

Bitter orange (Citrus aurautium L. ) rootstock is considered one of the good rootstocks for most types of citrus, being a good and suitable rootstock in medium and heavy lands, as it withstands high soil moisture and inappropriate environmental conditions compared to the other rootstocks, in addition to its compatibility with most types and varieties of citrus, and it is a source commonly used in Iraq. Local oranges (Citrus sinensis L.) are a popular variety in Iraqi orchards, where they are grown with palm trees and in open orchards in home gardens. Environmental conditions are considered one of the most important factors that directly or indirectly affect the success of the grafting process in citrus. The date of grafting has a significant impact on the success of the grafting process, whose success is related to the strongly and consistency of the graft and rootstock, and then the formation of callus tissue is followed by steps that lead to the emergence of the carrier vessels represented with wood and bark for graft and their association with the vessels carrying the rootstock, and then complete the docking process (Hartmann et al., 2002).

The weak and slow growth of grafts buds in the grafting process is one of the major obstacles to citrus seedlings grafted in nurseries, so fertilization of its various chemical, organic and biological types is one of the most important agricultural processes that are carried out on grafted citrus seedlings to improve the nutritional status of the seedlings, which is reflected positively on their vegetative growth, and is considered adequate quantities of major elements, especially nitrogen, phosphorous and potassium, are necessary for the growth of citrus plants (Obreza et al., 2008), and

Corresponding Author: Ayad Hani Ismail Al-Allaf, Department of Horticulture and Garden Engineering, College of Agriculture and Forestry, University of Mosul, Iraq. 
liquid organic fertilizers are one of the most important clean alternatives to the nutrients needed for fruit seedlings because they contain some organic acids such as humic and fulvic acids and amino acids and other materials characterized by cheap price, ease of use, low pollution to the environment and agricultural products, and their contribution to improving the physical, chemical, and biological properties of the soil (Hassan et al., 2010). On the other hand, bio-fertilizers are fertilizers that contain microorganisms that are able to supply plants with nutrients in a ready way in the cultivated soil such as nitrogen, phosphorus and potassium so that the roots of the seedlings can absorb and benefit from them in addition to reducing the degree of soil interaction $(\mathrm{pH})$ Which in turn leads to facilitate the microelements needed by the plant, as well as providing them with stimulants for the growth of plants such as hormones and growth regulators such as auxins, gibberellins and cytokinins (Mohamed and Massoud, 2017). This study came to determine the appropriate spring grafting date for grafting local oranges on bitter orange rootstock and producing grafted local orange seedlings ready for planting in the orchard as soon as possible by studying the effects of the interaction between chemical, organic and bio-fertilizers on the growth of grafts.

\section{Materials and Methods}

Research was carried out in the wooden canopy of the Department of Horticulture and Garden Engineering / Faculty of Agriculture and Forestry, Mosul University during the growth season 2018 to demonstrate the effect of two dates for spring grafting $\left(2^{\text {nd }}\right.$ and $17^{\text {th }}$ April) with local oranges (Citrus sinensis) seedlings grafted on bitter orange (Citrus aurantium) rootstock and the addition of chemical fertilization (NPK) and liquid organic (Nutrigreen) and three types of bio-fertilizers including, Biogen, Potasiomag and Fulzyme in the subsequent growth of grafted seedlings

Seedlings were selected as a two-year-old origin planted in $8 \mathrm{~kg}$ plastic containers containing loamy soil and animal fertilizer (sheep residue) at a ratio of $1: 3$. Local orange grafts branches were taken from the same mature year growths and from strong and productive trees from sicknesses and insects from the local gardens in Mosul city. The grafts were prepared in the grafting dates and immersed in concentrations of growth regulators $(100 \mathrm{mg} / \mathrm{L}$ IAA $+50 \mathrm{mg} / \mathrm{L}$ IBA for 10 seconds.

The experiment was designed according to the split-split system in a factorial experiment using the Completely Randomized Block Design (R.C.B.D). Three factors consist of two grafting dates, two concentrations of compound chemical fertilizer, seven concentrations of bio-fertilizers and liquid organic fertilizers. Thus, the number of treatments was 28 treatments with three replicates, so the number of experimental units reached 84 units and by 5 seedlings per treatment in each replicates, thus the number of seedlings used in the experiment 420 seedlings.

The T-budding grafting was conducted in the spring of 2018 with two dates (April 2nd and $17 \mathrm{th})$ at a height of $(15-20 \mathrm{~cm})$ above the soil surface level. After bud burst, the grafted seedlings were fertilized with three types of fertilizers: fertilizer with compound fertilizer (20:20:20) NPK, where it was added at $30 \mathrm{~g} / \mathrm{seedling}$ for two batches, the first was added by $15 \mathrm{~g}$ on (21 March), while the second batch was added with the same amount on (2nd May) and organic fertilization was added through the liquid Nutrigreen fertilizer at a concentration of $6 \mathrm{ml} /$ liter for two batches, the first on (March 26) and the second (May 3rd), then bio-fertilization was added through by three types of fertilizers including Biogen was added in two concentrations of 3 and $6 \mathrm{~g}$ per seedling, Potasiomag was added in two concentrations of 5 and $10 \mathrm{~g}$ per seedling and Fulzyme was added a concentrations of $1 \mathrm{~g}$ per seedling which was added in one batch on $21^{\text {st }}$ March.

At the end of the study, the following characteristics were measured:

$$
\text { Percentage of successful grafts }=\frac{\text { Number of successful grafts }}{\text { Total number of grafted seedlings }} \times 100
$$

- Number of leaves

- Leaf content of mineral elements:

Nitrogen: It was determined using the Kjeldahl method according to the method adopted by Bremner and Mulvaney (1982).

Phosphorus: It was determined using Spectrophotometer according to the method described by Page et al. (1982). 
Potassium and Sodium: It was determined by the Flame-photometer according to the method proposed by Horneck and Hanson (1998).

\section{Experimental design and statistical Analysis}

The complete randomized block design was adopted for this experiment. The statistical analysis of the present data was carried out according to SAS / STAT (2001). Averages were compared using the Duncan test at 5\% level according to Duncan (1955).

\section{Results}

\section{Percentage of successful grafting}

Data in table (1) showed that the first grafting date $\left(2^{\text {nd }}\right.$ April) was significantly superior to the second vaccination date $\left(17^{\text {th }}\right.$ April) in the percentage of successful grafting, where the values for the two dates were 44.76 and $31.42 \%$, respectively, while the untreated seedlings (control) of NPK fertilizer had the highest percentage of successful grafts, reaching $43.81 \%$, and significantly superior to fertilization through treatment NPK at a concentration of $30 \mathrm{~g} /$ seedling in which this percentage reached $32.38 \%$, and the results also showed that all bio-fertilizer treatments significantly outperformed the control treatment in the percentage of successful grafts, especially treatments of $6 \mathrm{~g}$ Biogen fertilizer and $10 \mathrm{~g}$ Potasiomag fertilizer and reached $45.00 \%$ for two treatments compared to the control treatment, which had the lowest values and reached $25.00 \%$.

Table 1: Effect of date of grafting and chemical, organic and bio-fertilizers on the percentage of success grafting of grafted local orange seedlings

\begin{tabular}{|c|c|c|c|c|c|c|c|c|c|}
\hline \multirow[b]{2}{*}{$\begin{array}{l}\text { Date of } \\
\text { grafting }\end{array}$} & \multirow{2}{*}{$\begin{array}{c}\text { Chemical } \\
\text { fertilizers } \\
\text { NPK }\end{array}$} & \multicolumn{7}{|c|}{ Organic and bio-fertilizers } & \multirow[b]{2}{*}{$\begin{array}{c}\text { Date X } \\
\text { NPK }\end{array}$} \\
\hline & & $\begin{array}{c}\text { Control } \\
\text { Zero }\end{array}$ & $\begin{array}{c}\text { Biogen } \\
3 \text { g. }\end{array}$ & $\begin{array}{c}\text { Biogen } \\
6 \mathrm{~g} .\end{array}$ & $\begin{array}{c}\text { Potasioma } \\
5 \mathrm{~g} .\end{array}$ & $\begin{array}{c}\text { otasioma } \\
10 \mathrm{~g} .\end{array}$ & $\begin{array}{c}\text { Fulzyme } \\
1 \mathrm{~g} .\end{array}$ & $\begin{array}{c}\text { Nutrigreen } \\
6 \mathrm{~m} / \mathrm{L} .\end{array}$ & \\
\hline \multirow{2}{*}{$\begin{array}{l}\text { First } \\
\text { date } 2 / 4\end{array}$} & Zero & $\begin{array}{c}26.67 \\
d\end{array}$ & $\begin{array}{c}66.67 \\
a b\end{array}$ & $\begin{array}{c}66.67 \\
a b\end{array}$ & $\begin{array}{c}53.33 \\
\text { b-c }\end{array}$ & $\begin{array}{c}80.00 \\
a\end{array}$ & $\begin{array}{c}33.33 \\
\text { c-e }\end{array}$ & $\begin{array}{c}46.67 \\
b-d\end{array}$ & $53.33 \mathrm{a}$ \\
\hline & $30 \mathrm{~g}$. & 33.33 & 40.00 & 40.00 & 33.33 & 40.00 & 33.33 & 33.33 & $36.19 b$ \\
\hline \multirow{2}{*}{$\begin{array}{l}\text { Second } \\
\text { date } 17 / 4\end{array}$} & Zero & $\begin{array}{c}20.00 \\
\mathrm{e}\end{array}$ & $\begin{array}{c}46.67 \\
b-d\end{array}$ & $\begin{array}{c}53.33 \\
b c\end{array}$ & $\begin{array}{c}40.00 \\
c-e\end{array}$ & $\begin{array}{c}26.67 \\
d\end{array}$ & $\begin{array}{c}26.67 \\
d\end{array}$ & $\begin{array}{c}26.67 \\
d\end{array}$ & $34.28 b$ \\
\hline & $30 \mathrm{~g}$. & $\begin{array}{c}20.00 \\
\mathrm{e}\end{array}$ & $\begin{array}{c}20.00 \\
\mathrm{e}\end{array}$ & $\begin{array}{c}20.00 \\
\mathrm{e}\end{array}$ & $\begin{array}{c}40.00 \\
c-e\end{array}$ & $\begin{array}{c}33.33 \\
c-e\end{array}$ & $\begin{array}{c}26.67 \\
d\end{array}$ & $\begin{array}{c}40.00 \\
c-e\end{array}$ & $28.57 \mathrm{~b}$ \\
\hline \multirow{2}{*}{$\begin{array}{l}\text { Date } X \\
\text { Bio and } \\
\text { organic } \\
\text { fertilizers }\end{array}$} & $\begin{array}{l}\text { First } \\
\text { date } \\
2 / 4\end{array}$ & $\begin{array}{c}30.00 \\
\mathrm{~cd}\end{array}$ & $\begin{array}{c}53.33 \\
\mathrm{ab}\end{array}$ & $\begin{array}{c}53.33 \\
a b\end{array}$ & $\begin{array}{c}43.33 \\
b c\end{array}$ & $\begin{array}{c}60.00 \\
\mathrm{a}\end{array}$ & $\begin{array}{c}33.33 \\
\mathrm{~cd}\end{array}$ & $\begin{array}{c}40.00 \\
b c\end{array}$ & \begin{tabular}{|c|}
$\begin{array}{c}\text { Date of } \\
\text { grafting }\end{array}$ \\
$44.76 \mathrm{a}$
\end{tabular} \\
\hline & $\begin{array}{l}\text { Second } \\
\text { date } 17 / 4\end{array}$ & $\begin{array}{c}20.00 \\
\mathrm{~d}\end{array}$ & $\begin{array}{c}33.33 \\
\mathrm{~cd}\end{array}$ & $\begin{array}{c}36.66 \\
b-d\end{array}$ & $\begin{array}{c}40.00 \\
b c\end{array}$ & $\begin{array}{c}30.00 \\
\mathrm{~cd}\end{array}$ & $\begin{array}{c}26.66 \\
\mathrm{~cd}\end{array}$ & $\begin{array}{c}33.33 \\
\mathrm{~cd}\end{array}$ & $31.42 b$ \\
\hline \multirow{2}{*}{$\begin{array}{l}\text { Chemical } \\
\text { fertilizers } \\
X \text { bio ad } \\
\text { organic } \\
\text { fertilizers }\end{array}$} & Zero & $\begin{array}{c}23.33 \\
d\end{array}$ & $\begin{array}{c}56.66 \\
a\end{array}$ & $\begin{array}{c}60.00 \\
\mathrm{a}\end{array}$ & $\begin{array}{l}46.66 \\
a-c\end{array}$ & $\begin{array}{c}53.33 \\
a b\end{array}$ & $\begin{array}{l}30.00 \\
\mathrm{~cd}\end{array}$ & $\begin{array}{c}36.66 \\
b-d\end{array}$ & $\begin{array}{c}\begin{array}{c}\text { NPK } \\
\text { fertilizers }\end{array} \\
43.81 \mathrm{a}\end{array}$ \\
\hline & 30 g. & $\begin{array}{c}26.66 \\
d\end{array}$ & $\begin{array}{l}30.00 \\
\mathrm{~cd}\end{array}$ & $\begin{array}{c}30.00 \\
\mathrm{~cd}\end{array}$ & $\begin{array}{c}36.66 \\
b-d\end{array}$ & $\begin{array}{c}36.66 \\
b-d\end{array}$ & $\begin{array}{c}30.00 \\
c-d\end{array}$ & $\begin{array}{c}36.66 \\
b-d\end{array}$ & $32.38 b$ \\
\hline \multicolumn{2}{|c|}{$\begin{array}{l}\text { Bio and organic } \\
\text { fertilizers }\end{array}$} & $\begin{array}{c}25.00 \\
\mathrm{c}\end{array}$ & $\begin{array}{c}43.33 \\
\mathrm{a}\end{array}$ & $\begin{array}{c}45.00 \\
\mathrm{a}\end{array}$ & $\begin{array}{c}41.66 \\
\mathrm{a}\end{array}$ & $\begin{array}{c}45.00 \\
\mathrm{a}\end{array}$ & $\begin{array}{c}30.00 \\
\mathrm{bc}\end{array}$ & $\begin{array}{c}36.66 \\
a b\end{array}$ & \\
\hline
\end{tabular}

*Mean averages followed by different letters indicate significant differences between them according to Duncan polynomial test at a level of $5 \%$

With regard to the effect of interaction between the dates of grafting and chemical fertilization (NPK), it was obvious that untreated seedlings (control) of NPK fertilizer for grafted seedlings at the first grafting date had had the highest percentage successful grafts, while the lowest value of this one was obtained from adding $30 \mathrm{~g}$ of NPK fertilizer at the second grafting date.

As for the effect of interaction between the dates of grafting and the organic and bio-fertilizers, it was showed that the addition of Potasiomag fertilizer at a concentration of $10 \mathrm{~g}$ in the first grafting date gave the highest percentage of successful grafts and significantly outperformed other treatments except for the two treatments adding Biogen fertilizer at concentrations 3 and $6 \mathrm{~g}$ in the first grafting 
date, where there were no significant differences between them, while The lowest value obtained was as a result of the control treatment of organic and bio-fertilizers in the second grafting date.

With regard to the effect of the interaction between chemical fertilization (NPK) and bio- and organic fertilizers, it was found that the highest significant percentage of successful grafts reached $(60.00 \%)$ was obtained from untreated seedlings (control) of NPK $+6 \mathrm{~g}$ Biogen fertilizer followed by untreated seedlings (control) of NPK $+3 \mathrm{~g}$ Biogen fertilizer where it reached $56.66 \%$, while untreated seedlings (control) of NPK + untreated seedlings (control) of organic and bio-fertilizers recorded the lowest percentage was recorded at $23.33 \%$.

As for the effect of the interaction among the dates of grafting, chemical fertilization (NPK) and organic and bio-fertilizers, it was clear that the highest significant percentage of successful grafts $(80 \%)$ was obtained as a result of the triple interaction among control treatment of NPK $+10 \mathrm{~g}$ Potasiomag fertilizer at the first grafting date, and recorded significant superiority over other treatments except the triple interaction among control treatment of NPK + all concentrations of Biogen fertilizer at the first grafting date.

\section{Number of leaves}

As shown in table (2), it was showed that the first grafting date was superior in giving the highest number of leaves compared to the second grafting date that gave the lowest one, as the control of NPK fertilizer was significantly superior to the treatment of $30 \mathrm{~g}$ of NPK fertilizer, and the highest significant value of the one was recorded as a result of adding the Potasiomag fertilizer at a concentration of $5 \mathrm{~g}$ while the lowest value was obtained from the control treatment.

Table 2: Effect of date of grafting and chemical, organic and bio-fertilizers on the number of leaves of grafted local orange seedlings

\begin{tabular}{|c|c|c|c|c|c|c|c|c|c|}
\hline \multirow[b]{2}{*}{$\begin{array}{c}\text { Date of } \\
\text { grafting }\end{array}$} & \multirow{2}{*}{$\begin{array}{c}\text { Chemical } \\
\text { fertilizers } \\
\text { NPK }\end{array}$} & \multicolumn{7}{|c|}{ Organic and bio-fertilizers } & \multirow[b]{2}{*}{$\begin{array}{l}\text { Date X } \\
\text { NPK }\end{array}$} \\
\hline & & $\begin{array}{c}\text { Control } \\
\text { Zero }\end{array}$ & $\begin{array}{l}\text { Biogen } \\
3 \text { g. }\end{array}$ & $\begin{array}{l}\text { Biogen } \\
6 \text { g. }\end{array}$ & $\begin{array}{c}\text { Potasiomag } \\
5 \mathrm{~g} .\end{array}$ & $\begin{array}{l}\text { otasiome } \\
10 \mathrm{~g} .\end{array}$ & $\begin{array}{l}\text { Fulzyme } \\
1 \mathrm{~g} .\end{array}$ & $\begin{array}{c}\text { Nutrigreen } \\
6 \mathrm{~m} / \mathrm{L} .\end{array}$ & \\
\hline \multirow{2}{*}{$\begin{array}{l}\text { First } \\
\text { date } \\
2 / 4\end{array}$} & Zero & $\begin{array}{c}26.00 \\
\text { e-h }\end{array}$ & $\begin{array}{c}37.19 \\
b-d\end{array}$ & $\begin{array}{c}40.16 \\
a-c\end{array}$ & $\begin{array}{c}47.00 \\
\mathrm{a}\end{array}$ & $\begin{array}{c}41.66 \\
a b\end{array}$ & $\begin{array}{c}35.83 \\
b-e\end{array}$ & $\begin{array}{c}35.83 \\
b-e\end{array}$ & $37.67 \mathrm{a}$ \\
\hline & $30 \mathrm{~g}$. & $\begin{array}{c}25.00 \\
\mathrm{f}-\mathrm{h}\end{array}$ & $\begin{array}{c}30.00 \\
\mathrm{~d}-\mathrm{g}\end{array}$ & $\begin{array}{c}31.50 \\
\mathrm{c}-\mathrm{g}\end{array}$ & $\begin{array}{c}36.00 \\
b-d\end{array}$ & $\begin{array}{c}29.44 \\
\mathrm{~d}-\mathrm{g}\end{array}$ & $\begin{array}{c}29.66 \\
\mathrm{~d}-\mathrm{g}\end{array}$ & $\begin{array}{c}32.33 \\
\mathrm{~b}-\mathrm{g}\end{array}$ & $30.56 b$ \\
\hline \multirow{2}{*}{$\begin{array}{l}\text { Second } \\
\text { date } \\
17 / 4\end{array}$} & Zero & $\begin{array}{c}18.33 \\
\mathrm{c}\end{array}$ & $\begin{array}{c}33.55 \\
b-f\end{array}$ & $\begin{array}{c}30.41 \\
c-g\end{array}$ & $\begin{array}{c}34.00 \\
b-f\end{array}$ & $\begin{array}{c}33.33 \\
b-f\end{array}$ & $\begin{array}{c}32.88 \\
b-f\end{array}$ & $\begin{array}{c}30.81 \\
\mathrm{c}-\mathrm{g}\end{array}$ & $30.57 b$ \\
\hline & $30 \mathrm{~g}$. & $\begin{array}{l}23.00 \\
\mathrm{gh}\end{array}$ & $\begin{array}{c}32.66 \\
b-g\end{array}$ & $\begin{array}{c}30.22 \\
\mathrm{~d}-\mathrm{g}\end{array}$ & $\begin{array}{c}32.50 \\
b-g\end{array}$ & $\begin{array}{c}34.00 \\
b-f\end{array}$ & $\begin{array}{l}31.00 \\
\mathrm{c}-\mathrm{g}\end{array}$ & $\begin{array}{c}31.44 \\
\mathrm{c}-\mathrm{g}\end{array}$ & $30.59 b$ \\
\hline \multirow{2}{*}{$\begin{array}{l}\text { Date X Bio } \\
\text { and organic } \\
\text { fertilizers }\end{array}$} & \multirow{2}{*}{ 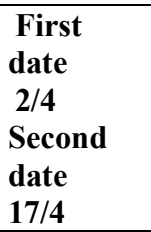 } & $\begin{array}{c}25.50 \mathrm{c} \\
\mathrm{d}\end{array}$ & $\begin{array}{c}33.59 \\
b\end{array}$ & $\begin{array}{c}35.83 \mathrm{a} \\
\mathrm{b}\end{array}$ & $\begin{array}{c}41.50 \\
\mathrm{a}\end{array}$ & $\begin{array}{c}35.55 \\
\mathrm{ab}\end{array}$ & $\begin{array}{c}32.75 \\
b\end{array}$ & $\begin{array}{c}34.08 \\
b\end{array}$ & \multirow{2}{*}{ 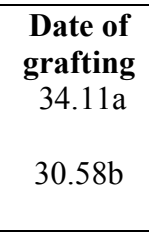 } \\
\hline & & $\begin{array}{c}20.66 \\
d\end{array}$ & $\begin{array}{c}33.11 \\
\text { bc }\end{array}$ & $\begin{array}{c}30.31 \\
\mathrm{bc}\end{array}$ & $\begin{array}{c}33.25 \\
b\end{array}$ & $\begin{array}{c}33.66 \\
b\end{array}$ & $\begin{array}{c}31.94 \\
b\end{array}$ & $\begin{array}{c}31.13 \\
b c\end{array}$ & \\
\hline \multirow{2}{*}{$\begin{array}{l}\text { Chemical } \\
\text { fertilizers X } \\
\text { bio ad } \\
\text { organic } \\
\text { fertilizers }\end{array}$} & Zero & $\begin{array}{c}22.16 \\
\mathrm{~d}\end{array}$ & $\begin{array}{c}35.37 \\
a-c\end{array}$ & $\begin{array}{c}35.29 \\
\mathrm{a}-\mathrm{c}\end{array}$ & $\begin{array}{c}40.50 \\
\mathrm{a}\end{array}$ & $\begin{array}{c}37.83 \\
\mathrm{ab}\end{array}$ & $\begin{array}{c}34.36 \\
a-c\end{array}$ & $\begin{array}{c}33.32 \\
\text { bc }\end{array}$ & $\begin{array}{c}\text { NPK } \\
\text { fertilizers } \\
34.12 \mathrm{a}\end{array}$ \\
\hline & $30 \mathrm{~g}$. & $\begin{array}{c}24.00 \\
\mathrm{~d}\end{array}$ & $\begin{array}{c}31.33 \\
\mathrm{bc}\end{array}$ & $\begin{array}{c}30.86 \\
\mathrm{c} \\
\end{array}$ & $\begin{array}{c}34.25 \\
\mathrm{a}-\mathrm{c}\end{array}$ & $\begin{array}{c}31.38 \\
\mathrm{bc}\end{array}$ & $\begin{array}{c}30.33 \\
\mathrm{c} \\
\end{array}$ & $\begin{array}{c}31.88 \\
\mathrm{bc}\end{array}$ & $30.57 b$ \\
\hline \multicolumn{2}{|c|}{$\begin{array}{l}\text { Bio and organic } \\
\text { fertilizers }\end{array}$} & $23.08 \mathrm{c}$ & $\begin{array}{c}33.35 \\
\mathrm{ab}\end{array}$ & $\begin{array}{c}33.07 \\
\mathrm{ab}\end{array}$ & $37.37 \mathbf{a}$ & $\begin{array}{c}34.61 \\
\mathrm{ab}\end{array}$ & $\begin{array}{c}32.34 \\
\mathrm{~b}\end{array}$ & $\begin{array}{c}32.60 \\
\mathrm{~b}\end{array}$ & \\
\hline
\end{tabular}

*Mean averages followed by different letters indicate significant differences between them according to Duncan polynomial test at a level of $5 \%$

With regard to the effect of interaction between the dates of grafting and chemical fertilization (NPK), it was obvious that the control treatment of NPK fertilizer at the first grafting date had the highest significant value in the number of leaves as compared to the other treatments, it was reached 37.67 leaves, while there were no significant differences between other treatments.

As for the effect of interaction between the dates of grafting and the organic and bio-fertilizers, it was showed that the addition of Potasiomag fertilizer at a concentration of $5 \mathrm{~g}$ at the first grafting 
date achieved the highest significant value in the number of leaves compared to the control treatment at the second grafting date, which gave the lowest value.

With regard to the effect of the interaction between chemical fertilization (NPK) and bio- and organic fertilizers, it was found that the highest significant value of number of leaves was obtained from the control treatment of NPK fertilizer $+5 \mathrm{~g}$ of Potasiomag fertilizer as compared to the control treatment of both chemical, organic and bio-fertilizers, which had the lowest one.

As for the effect of the interaction among the dates of grafting, chemical fertilization (NPK) and organic and bio-fertilizers, it was clear that the control treatment of NPK fertilizer $+5 \mathrm{~g}$ of Potasiomag fertilizer at the first grafting date achieved the highest number of leaves and significantly outperformed other treatments especially resulting from the addition of NPK chemical, organic and bio-fertilizers at the second grafting date.

\section{Nitrogen content in the leaves}

Data in table (3) showed that, the grafted seedlings in the first grafting date exceled significantly in the percentage of nitrogen in the leaves compared to the grafted seedlings in the second grafting date which gave the lowest percentage, in addition, the control treatment significantly outperformed the leaf content of nitrogen over the treatment of $30 \mathrm{~g}$ of NPK fertilizer, also all organic and bio-fertilizers affected significantly the leaf content of nitrogen, especially the concentration of 5 $\mathrm{g}$ of Potasiomag fertilizer, which had the highest percentage and significantly superior to other treatments except for the concentration of $10 \mathrm{~g}$ of the same fertilizer and the concentrations of 3 and 6 $\mathrm{g}$ of Biogen fertilizer, which in turn did not differ significantly from the two treatments $1 \mathrm{~g}$ of Fulzyme fertilizer and $6 \mathrm{ml}$ of Nutrigreen fertilizer, while the control treatment recorded the lowest percentage of this one.

Table 3: Effect of date of grafting and chemical, organic and bio-fertilizers on the nitrogen content "\%" in the leaves of grafted orange seedlings

\begin{tabular}{|c|c|c|c|c|c|c|c|c|c|}
\hline \multirow[b]{2}{*}{$\begin{array}{c}\text { Date of } \\
\text { grafting }\end{array}$} & \multirow{2}{*}{$\begin{array}{c}\text { Chemical } \\
\text { fertilizers } \\
\text { NPK }\end{array}$} & \multicolumn{7}{|c|}{ Organic and bio-fertilizers } & \multirow[b]{2}{*}{$\begin{array}{l}\text { Date X } \\
\text { NPK }\end{array}$} \\
\hline & & $\begin{array}{c}\text { Control } \\
\text { Zero }\end{array}$ & $\begin{array}{l}\text { Biogen } \\
3 \text { g. }\end{array}$ & $\begin{array}{l}\text { Biogen } \\
6 \text { g. }\end{array}$ & $\begin{array}{l}\text { Potasiomag } \\
5 \mathrm{~g} .\end{array}$ & $\begin{array}{c}\text { Potasiomag } \\
10 \mathrm{~g} .\end{array}$ & $\begin{array}{l}\text { Fulzyme } \\
1 \mathrm{~g} .\end{array}$ & $\begin{array}{c}\text { Nutrigreen } \\
6 \mathrm{~m} / \mathrm{L} .\end{array}$ & \\
\hline \multirow{4}{*}{$\begin{array}{l}\text { First } \\
\text { date } \\
2 / 4\end{array}$} & \multirow{2}{*}{ Zero } & 1.62 & 2.13 & 2.29 & 2.42 & 2.37 & 2.13 & 1.98 & \multirow{2}{*}{$2.13 \mathrm{a}$} \\
\hline & & ef & $a-d$ & $a-c$ & $\mathrm{a}$ & $\mathrm{ab}$ & $a-d$ & $a-f$ & \\
\hline & \multirow[b]{2}{*}{$30 \mathrm{~g}}$. & 1.57 & 2.03 & 2.07 & 2.05 & 2.04 & 1.93 & 1.97 & \multirow[b]{2}{*}{$1.95 \mathrm{~b}$} \\
\hline & & $\mathrm{f}$ & a-e & a-e & $a-f$ & $a-f$ & $b-f$ & $a-f$ & \\
\hline \multirow{4}{*}{$\begin{array}{l}\text { Second } \\
\text { date } \\
17 / 4\end{array}$} & \multirow{2}{*}{ Zero } & 1.62 & 1.97 & 1.95 & 2.20 & 2.01 & 1.83 & 1.82 & \multirow{2}{*}{$1.91 \mathrm{~b}$} \\
\hline & & ef & $a-f$ & $a-f$ & $a-d$ & $a-f$ & $c-f$ & $c-f$ & \\
\hline & \multirow{2}{*}{30 g. } & 1.59 & 1.92 & 1.90 & 2.04 & 2.01 & 1.77 & 1.92 & \multirow{2}{*}{$1.88 \mathrm{~b}$} \\
\hline & & $\mathrm{f}$ & $\mathrm{b}-\mathrm{f}$ & $b-f$ & $a-f$ & $a-f$ & $\mathrm{~d}-\mathrm{f}$ & $b-f$ & \\
\hline \multirow{3}{*}{$\begin{array}{l}\text { Date X } \\
\text { Bio and } \\
\text { organic } \\
\text { fertilizers }\end{array}$} & \multirow{3}{*}{$\begin{array}{l}\text { First } \\
\text { date } \\
2 / 4 \\
\text { Second } \\
\text { date } 17 / 4 \\
\end{array}$} & 1.59 & 2.08 & 2.18 & 2.23 & 2.20 & 2.03 & 1.98 & \multirow{3}{*}{$\begin{array}{c}\begin{array}{c}\text { Date of } \\
\text { grafting }\end{array} \\
2.04 \mathrm{a} \\
1.90 \mathrm{~b}\end{array}$} \\
\hline & & $\mathrm{d}$ & $a-c$ & $a b$ & $\mathrm{a}$ & $\mathrm{a}$ & $a-c$ & $a-c$ & \\
\hline & & $\begin{array}{c}1.60 \\
\mathrm{~d}\end{array}$ & $\begin{array}{l}1.95 \\
\mathrm{a}-\mathrm{c}\end{array}$ & $\begin{array}{c}1.93 \\
\mathrm{a}-\mathrm{c}\end{array}$ & $\begin{array}{c}2.12 \\
\mathrm{a}-\mathrm{c}\end{array}$ & $\begin{array}{c}2.01 \\
\mathrm{a}-\mathrm{c}\end{array}$ & $\begin{array}{c}1.80 \\
\mathrm{~cd}\end{array}$ & $\begin{array}{l}1.87 \\
b-d\end{array}$ & \\
\hline \multirow{2}{*}{$\begin{array}{l}\text { Chemical } \\
\text { fertilizers } \\
\mathrm{X} \text { bio ad } \\
\text { organic } \\
\text { fertilizers }\end{array}$} & Zero & $\begin{array}{c}1.62 \\
\text { de }\end{array}$ & $\begin{array}{c}2.05 \\
a-c\end{array}$ & $\begin{array}{c}2.12 \\
a-c\end{array}$ & $\begin{array}{c}2.31 \\
\mathrm{a}\end{array}$ & $\begin{array}{c}2.19 \\
\mathrm{ab}\end{array}$ & $\begin{array}{c}1.98 \\
\text { bc }\end{array}$ & $\begin{array}{l}1.90 \\
b-d\end{array}$ & $\begin{array}{c}\text { NPK } \\
\text { fertilizers }\end{array}$ \\
\hline & $30 \mathrm{~g}$. & $\begin{array}{c}1.58 \\
\mathrm{e}\end{array}$ & $\begin{array}{l}1.97 \\
\mathrm{bc}\end{array}$ & $\begin{array}{c}1.99 \\
\mathrm{bc}\end{array}$ & $\begin{array}{c}2.04 \\
a-c\end{array}$ & $\begin{array}{c}2.02 \\
a-c\end{array}$ & $\begin{array}{l}1.85 \\
\mathrm{c}-\mathrm{e}\end{array}$ & $\begin{array}{l}1.95 \\
\mathrm{bc}\end{array}$ & $1.91 \mathrm{~b}$ \\
\hline \multicolumn{2}{|c|}{$\begin{array}{l}\text { Bio and organic } \\
\text { fertilizers }\end{array}$} & $\begin{array}{c}1.60 \\
\mathrm{c}\end{array}$ & $\begin{array}{c}2.01 \\
\mathrm{ab}\end{array}$ & $\begin{array}{c}2.05 \\
\mathrm{ab}\end{array}$ & $\begin{array}{c}2.17 \\
\mathrm{a}\end{array}$ & $\begin{array}{c}2.11 \\
\mathrm{ab}\end{array}$ & $\begin{array}{c}1.91 \\
\mathrm{~b}\end{array}$ & $\begin{array}{c}1.92 \\
\mathrm{~b}\end{array}$ & \\
\hline
\end{tabular}

*Mean averages followed by different letters indicate significant differences between them according to Duncan polynomial test at a level of $5 \%$

With regard to the effect of interaction between the dates of grafting and chemical fertilization (NPK), it was obvious that the control treatment of NPK fertilizer at the first grafting date gave the highest significant percentage for the leaf content of nitrogen and significantly superior to other treatments. 
As for the effect of interaction between the dates of grafting and the organic and bio-fertilizers, it was showed that treatments 5 and $10 \mathrm{~g}$ of Potasiomag fertilizer added to grafted seedlings at the first grafting date achieved the highest significant percentage of nitrogen in the leaves compared to the control treatment of organic and bio-fertilizers in the first and second grafting dates where they recorded the lowest percentage of this one.

With regard to the effect of the interaction between chemical fertilization (NPK) and bio- and organic fertilizers, it was found that the highest percentage of nitrogen in the leaves was obtained from the control treatment of NPK +5 gm of Potasiomag fertilizer, and it significantly outperformed other treatments, especially NPK fertilizer + the control treatment of organic and bio-fertilizers, which gave the lowest percentages of this one.

As for the effect of the interaction among the dates of grafting, chemical fertilization (NPK) and bio- and organic fertilizers, it was clear that the control treatment of NPK fertilizer $+5 \mathrm{~g}$ of Potasiomag fertilizer at the first grafting date achieved the highest significant percentage for the leaf content of nitrogen and significantly superior to other treatments.

\section{Phosphorus content in the leaves}

As shown in table (4), it was showed that the date of grafting did not have any significant effect on the percentage of phosphorus in the leaves as there were no significant differences between the two dates, while the control treatment of NPK fertilizer scored significantly and had the highest percentage of this one compared to adding $30 \mathrm{~g}$ of NPK fertilizer, which achieved the lowest percentage, and the addition of bio-fertilizers had a significant increase in the percentage of phosphorous in the leaves, especially when adding bio-fertilizer "Fulzame" at a concentration of $1 \mathrm{~g} /$ seedling, which achieved the highest percentage compared to untreated seedlings (control), which gave the lowest percentage of this one.

Table 4: Effect of date of grafting and chemical, organic and bio-fertilizers on the phosphorus content "\%" in the leaves of grafted orange seedlings

\begin{tabular}{|c|c|c|c|c|c|c|c|c|c|}
\hline \multirow[b]{2}{*}{$\begin{array}{l}\text { Date of } \\
\text { grafting }\end{array}$} & \multirow{2}{*}{$\begin{array}{c}\text { Chemical } \\
\text { fertilizers } \\
\text { NPK }\end{array}$} & \multicolumn{7}{|c|}{ Organic and bio-fertilizers } & \multirow[b]{2}{*}{$\begin{array}{l}\text { Date X } \\
\text { NPK }\end{array}$} \\
\hline & & $\begin{array}{c}\text { Control } \\
\text { Zero }\end{array}$ & $\begin{array}{l}\text { Biogen } \\
\text { 3g. }\end{array}$ & $\begin{array}{l}\text { Biogen } \\
6 \mathrm{~g} .\end{array}$ & $\begin{array}{l}\text { Potasiomag } \\
5 \mathrm{~g} .\end{array}$ & $\begin{array}{l}\text { Potasiomag } \\
10 \mathrm{~g} .\end{array}$ & $\begin{array}{c}\text { Fulzyme } \\
\text { 1g. }\end{array}$ & $\begin{array}{l}\text { Nutrigreen } \\
\quad 6 \mathbf{m} / \mathbf{L} \text {. }\end{array}$ & \\
\hline \multirow{2}{*}{$\begin{array}{l}\text { First } \\
\text { date } \\
2 / 4\end{array}$} & Zero & $\begin{array}{c}0.228 \\
\mathrm{i}\end{array}$ & $\begin{array}{c}0.364 \\
\text { a-e }\end{array}$ & $\begin{array}{c}0.359 \\
b-f\end{array}$ & $\begin{array}{c}0.400 \\
\mathrm{ab}\end{array}$ & $\begin{array}{c}0.402 \\
\mathrm{ab}\end{array}$ & $\begin{array}{c}0.425 \\
\mathrm{a}\end{array}$ & $\begin{array}{c}0.384 \\
a-c\end{array}$ & $0.336 \mathrm{a}$ \\
\hline & $30 \mathrm{~g}$. & $\begin{array}{c}0.262 \\
\text { hi }\end{array}$ & $\begin{array}{c}0.299 \\
\text { e-h }\end{array}$ & $\begin{array}{c}0.298 \\
\text { e-h }\end{array}$ & $\begin{array}{c}0.326 \\
\mathrm{c}-\mathrm{g}\end{array}$ & $\begin{array}{c}0.353 \\
b-g\end{array}$ & $\begin{array}{c}0.367 \\
a-d\end{array}$ & $\begin{array}{c}0.309 \\
\text { d-h }\end{array}$ & $0.316 \mathrm{~b}$ \\
\hline \multirow{2}{*}{$\begin{array}{l}\text { Second } \\
\text { date } \\
17 / 4\end{array}$} & Zero & $\begin{array}{c}0.225 \\
\mathrm{i}\end{array}$ & $\begin{array}{c}0.322 \\
\text { c-h }\end{array}$ & $\begin{array}{c}0.360 \\
b-f\end{array}$ & $\begin{array}{c}0.353 \\
b-g\end{array}$ & $\begin{array}{c}0.374 \\
a-d\end{array}$ & $\begin{array}{c}0.346 \\
b-g\end{array}$ & $\begin{array}{c}0.339 \\
b-g\end{array}$ & $0.331 b$ \\
\hline & $30 \mathrm{~g}$. & $\begin{array}{c}0.263 \\
\mathrm{hi}\end{array}$ & $\begin{array}{l}0.334 \mathrm{c} \\
-\mathrm{g}\end{array}$ & $\begin{array}{c}0.294 \\
\text { g-h }\end{array}$ & $\begin{array}{c}0.352 \\
b-g\end{array}$ & $\begin{array}{c}0.330 \\
\mathrm{c}-\mathrm{g}\end{array}$ & $\begin{array}{c}0.359 \\
b-f\end{array}$ & $\begin{array}{c}0.338 \\
b-g\end{array}$ & $0.324 b$ \\
\hline \multirow{2}{*}{$\begin{array}{l}\text { Date } X \\
\text { Bio and } \\
\text { organic } \\
\text { fertilizers }\end{array}$} & \multirow{2}{*}{ 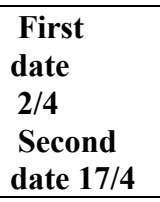 } & $\begin{array}{c}0.245 \\
\mathrm{~d}\end{array}$ & $\begin{array}{c}0.332 \\
\mathrm{c}\end{array}$ & $\begin{array}{c}0.329 \\
\mathrm{c}\end{array}$ & $\begin{array}{c}0.363 \\
\mathrm{a}-\mathrm{c}\end{array}$ & $\begin{array}{c}0.377 \\
\mathrm{ab}\end{array}$ & $\begin{array}{c}0.396 \\
\mathrm{a}\end{array}$ & $\begin{array}{c}0.346 \\
\text { bc }\end{array}$ & \multirow{2}{*}{$\begin{array}{c}\begin{array}{c}\text { Date of } \\
\text { grafting }\end{array} \\
0.341 \mathrm{a} \\
0.328 \mathrm{a}\end{array}$} \\
\hline & & $\begin{array}{c}0.244 \\
\mathrm{~d} \\
\end{array}$ & $\begin{array}{c}0.328 \\
\mathrm{c}\end{array}$ & $\begin{array}{c}0.327 \\
\mathrm{c}\end{array}$ & $\begin{array}{c}0.352 \\
\mathrm{bc}\end{array}$ & $\begin{array}{c}0.352 \\
\mathrm{bc}\end{array}$ & $\begin{array}{c}0.353 \\
\mathrm{bc}\end{array}$ & $\begin{array}{c}0.339 \\
\text { bc }\end{array}$ & \\
\hline \multirow{2}{*}{$\begin{array}{l}\text { Chemical } \\
\text { fertilizers } \\
\mathrm{X} \text { bio ad } \\
\text { organic } \\
\text { fertilizers }\end{array}$} & Zero & $\begin{array}{c}0.266 \\
\mathrm{~h}\end{array}$ & $\begin{array}{c}0.343 \\
\mathrm{~b}-\mathrm{e}\end{array}$ & $\begin{array}{c}0.360 \\
a-d\end{array}$ & $\begin{array}{c}0.376 \\
\mathrm{a}-\mathrm{c}\end{array}$ & $\begin{array}{c}0.388 \\
\mathrm{a}\end{array}$ & $\begin{array}{c}0.386 \\
\mathrm{ab}\end{array}$ & $\begin{array}{c}0.361 \\
\text { a-d }\end{array}$ & $\begin{array}{c}\begin{array}{c}\text { NPK } \\
\text { fertilizers }\end{array} \\
0.349 \mathrm{a}\end{array}$ \\
\hline & $30 \mathrm{~g}$. & $\begin{array}{c}0.262 \\
\mathrm{gh}\end{array}$ & $\begin{array}{c}0.316 \\
\text { ef }\end{array}$ & $\begin{array}{c}0.296 \\
\text { fg }\end{array}$ & $\begin{array}{c}0.339 \\
\text { c-e }\end{array}$ & $\begin{array}{c}0.341 \\
\mathrm{c}-\mathrm{e}\end{array}$ & $\begin{array}{c}0.363 \\
a-d\end{array}$ & $\begin{array}{c}0.324 \\
\mathrm{~d}-\mathrm{f}\end{array}$ & $0.320 \mathrm{~b}$ \\
\hline \multicolumn{2}{|c|}{$\begin{array}{l}\text { Bio and organic } \\
\text { fertilizers }\end{array}$} & $\begin{array}{c}0.244 \\
\mathrm{e}\end{array}$ & $\begin{array}{c}0.330 \\
\mathrm{~cd}\end{array}$ & $\begin{array}{c}0.328 \\
\mathrm{~d}\end{array}$ & $\begin{array}{c}0.358 \\
\mathrm{a}-\mathrm{c}\end{array}$ & $\begin{array}{c}0.364 \\
\mathrm{ab}\end{array}$ & $\begin{array}{c}0.374 \\
\mathrm{a}\end{array}$ & $\begin{array}{c}0.342 \\
\text { b-d }\end{array}$ & \\
\hline
\end{tabular}

With regard to the effect of interaction between the dates of grafting and chemical fertilization (NPK), it was obvious that the control treatment of NPK fertilizer at the first grafting date achieved significantly the highest percentage of phosphorus in the leaves and was significantly higher than other treatments. 
As for the effect of interaction between the dates of grafting and the organic and bio-fertilizers, it was showed that the grafted seedlings added to the bio-fertilizer "Fulzame" at a concentration of $1 \mathrm{~g}$ in the first grafting date achieved the highest percentage of phosphorus in the leaves and significantly outperformed the other treatments except adding the two concentrations 5 and $10 \mathrm{~g}$ of Potasiomag fertilizer at first grafting date, while the lowest percentage for this one was obtained by treating the control from the organic and bio-fertilizers for both grafting dates.

With regard to the effect of the interaction between chemical fertilization (NPK) and organic and bio- fertilizers, it was found that the control of NPK fertilizer $+10 \mathrm{~g}$ of Potasiomag fertilizer achieved the highest significant percentage of phosphorus in the leaves, while the lowest percentage was obtained through the control treatments for organic and bio-fertilizers.

As for the effect of the interaction among the dates of grafting, chemical fertilization (NPK) and organic and bio- fertilizers, it was clear that the control of NPK fertilizer $+1 \mathrm{~g}$ of Fulzame fertilizer for grafted seedlings at the first grafting date achieved the highest percentage of phosphorus in the leaves and significantly higher than other treatments, especially the control treatment of organic and bio-fertilizers for grafted seedlings at the first grafting date, which had the lowest percentage of this one.

\section{Potassium content in leaves}

The results indicated in table (5) showed that the grafting date of seedlings did not significantly affect the percentage of potassium in the leaves, as there were no significant differences between them, as the effect of chemical fertilization NPK did not have any significant effect on the percentage of potassium in the leaves where it was observed that there were no significant differences compared to the control, while the organic and bio-fertilizers significantly affected on percentage of potassium in the leaves, especially when adding bio-fertilizer "Potasiomag" in concentrations 5 and $10 \mathrm{~g}$, which had the highest percentage of potassium and did not differ significantly between them, but they were significantly superior to other fertilizer treatments, especially the treatment of control, which gave the lowest percentage of this one.

Table 5: Effect of date of grafting and chemical, organic and bio-fertilizers on the potassium content "\%" in the leaves of grafted orange seedlings

\begin{tabular}{|c|c|c|c|c|c|c|c|c|c|}
\hline \multirow[b]{2}{*}{$\begin{array}{l}\text { Date of } \\
\text { grafting }\end{array}$} & \multirow{2}{*}{$\begin{array}{c}\text { Chemical } \\
\text { fertilizers } \\
\text { NPK }\end{array}$} & \multicolumn{7}{|c|}{ Organic and bio-fertilizers } & \multirow[b]{2}{*}{$\begin{array}{c}\text { Date X } \\
\text { NPK }\end{array}$} \\
\hline & & $\begin{array}{c}\text { Control } \\
\text { Zero } \\
\end{array}$ & $\begin{array}{c}\text { Biogen } \\
3 \mathrm{~g} . \\
\end{array}$ & $\begin{array}{c}\text { Biogen } \\
6 \mathrm{~g} .\end{array}$ & $\begin{array}{c}\text { Potasiomag } \\
5 \mathrm{~g} .\end{array}$ & $\begin{array}{c}\text { Potasiomag } \\
10 \mathrm{~g} .\end{array}$ & $\begin{array}{c}\text { Fulzyme } \\
1 \mathrm{~g} .\end{array}$ & $\begin{array}{c}\text { Nutrigreen } \\
6 \mathrm{~m} / \mathrm{L} .\end{array}$ & \\
\hline \multirow{4}{*}{$\begin{array}{l}\text { First } \\
\text { date } \\
2 / 4\end{array}$} & \multirow{2}{*}{ Zero } & 1.32 & 2.53 & 2.22 & 2.55 & 2.80 & 2.41 & 2.29 & \multirow{2}{*}{$2.30 \mathrm{a}$} \\
\hline & & $\mathrm{f}$ & a-e & b-e & a-e & $\mathrm{a}$ & a-e & $a-e$ & \\
\hline & \multirow{2}{*}{$30 \mathrm{~g}}$. & 1.46 & 2.16 & 2.22 & 2.79 & 2.60 & 2.34 & 2.14 & \multirow{2}{*}{$2.24 \mathrm{a}$} \\
\hline & & $\mathrm{f}$ & $\mathrm{c}-\mathrm{e}$ & b-e & $\mathrm{ab}$ & $a-d$ & $\mathrm{a}-\mathrm{e}$ & $\mathrm{c}-\mathrm{e}$ & \\
\hline \multirow{4}{*}{$\begin{array}{l}\text { Second } \\
\text { date } 17 / 4\end{array}$} & \multirow{2}{*}{ Zero } & 1.32 & 2.14 & 2.51 & 2.70 & 2.58 & 2.29 & 2.00 & \multirow{2}{*}{$2.22 \mathrm{a}$} \\
\hline & & $\mathrm{f}$ & $\mathrm{c}-\mathrm{e}$ & a-e & $\mathrm{a}-\mathrm{c}$ & $a-d$ & a-e & e & \\
\hline & \multirow{2}{*}{$30 \mathrm{~g}$. } & 1.18 & 2.55 & 2.39 & 2.45 & 2.63 & 2.05 & 2.46 & \multirow{2}{*}{$2.24 \mathrm{a}$} \\
\hline & & $\mathrm{f}$ & $\mathrm{a}-\mathrm{e}$ & $\mathrm{a}-\mathrm{e}$ & $\mathrm{a}-\mathrm{e}$ & $\mathrm{a}-\mathrm{c}$ & de & $\mathrm{a}-\mathrm{e}$ & \\
\hline \multirow{4}{*}{$\begin{array}{l}\text { Date X } \\
\text { Bio and } \\
\text { organic } \\
\text { fertilizers }\end{array}$} & \multirow{2}{*}{$\begin{array}{l}\text { First } \\
\text { date } 2 / 4\end{array}$} & \multirow{2}{*}{$\begin{array}{c}1.39 \\
\mathrm{e}\end{array}$} & \multirow{2}{*}{$\begin{array}{c}2.34 \\
a-d\end{array}$} & \multirow{2}{*}{$\begin{array}{r}2.22 \\
b-d\end{array}$} & \multirow{2}{*}{$\begin{array}{c}2.67 \\
\mathrm{a}\end{array}$} & \multirow{2}{*}{$\begin{array}{c}2.70 \\
a\end{array}$} & \multirow{2}{*}{$\begin{array}{c}2.37 \\
\mathrm{a}-\mathrm{d}\end{array}$} & \multirow{2}{*}{$\begin{array}{c}2.22 \\
b-d\end{array}$} & \multirow{2}{*}{$\begin{array}{c}\begin{array}{c}\text { Date of } \\
\text { grafting }\end{array} \\
2.27 \mathrm{a}\end{array}$} \\
\hline & & & & & & & & & \\
\hline & \multirow{2}{*}{$\begin{array}{l}\text { Second } \\
\text { date 17/4 }\end{array}$} & 1.25 & 2.36 & 2.45 & 2.57 & 2.60 & 2.17 & 2.23 & \multirow{2}{*}{$2.23 \mathrm{a}$} \\
\hline & & $\mathrm{e}$ & $a-d$ & $a-d$ & $a-c$ & $\mathrm{ab}$ & $\mathrm{d}$ & $b-d$ & \\
\hline \multirow{4}{*}{$\begin{array}{l}\text { Chemical } \\
\text { fertilizers } \\
\text { X bio ad } \\
\text { organic } \\
\text { fertilizers }\end{array}$} & \multirow[t]{2}{*}{ Zero } & \multirow{2}{*}{$\begin{array}{c}1.32 \\
\mathrm{c}\end{array}$} & \multirow{2}{*}{$\begin{array}{c}2.35 \\
\mathrm{ab}\end{array}$} & \multirow{2}{*}{$\begin{array}{c}2.37 \\
\mathrm{ab}\end{array}$} & \multirow{2}{*}{$\begin{array}{c}2.63 \\
\mathrm{a}\end{array}$} & \multirow{2}{*}{$\begin{array}{c}2.69 \\
a\end{array}$} & \multirow{2}{*}{$\begin{array}{c}2.35 \\
\mathrm{ab}\end{array}$} & 2.14 & $\begin{array}{c}\text { NPK } \\
\text { fertilizers }\end{array}$ \\
\hline & & & & & & & & & $2.26 \mathrm{a}$ \\
\hline & $30 \mathrm{o}$ & 1.32 & 2.35 & 2.31 & 2.62 & 2.61 & 2.19 & 2.30 & $224 a$ \\
\hline & $30 \mathrm{~g} \cdot$ & $\mathrm{c}$ & $\mathrm{ab}$ & $\mathrm{ab}$ & $\mathrm{a}$ & $\mathrm{a}$ & $\mathrm{b}$ & $\mathrm{ab}$ & $2.24 \mathrm{a}$ \\
\hline Bio and or & anic & 1.32 & 2.35 & 2.34 & 2.62 & 2.65 & 2.27 & 2.22 & \\
\hline fertilizers & & $\mathrm{c}$ & $\mathrm{b}$ & $\mathrm{b}$ & $\mathrm{a}$ & $\mathrm{a}$ & $\mathrm{b}$ & $\mathrm{b}$ & \\
\hline
\end{tabular}


With regard to the effect of interaction between the dates of grafting and chemical fertilization (NPK), it was obvious that there was no significant effect between chemical fertilization (NPK) and the grafting dates of grafting seedlings on potassium content in the leaves.

As for the effect of interaction between the dates of grafting and the organic and bio-fertilizers, it was showed that the highest percentage of potassium in the leaves was obtained from the addition of Potasiomag fertilizer in the concentrations of 5 and $10 \mathrm{~g}$ for grafted seedlings at the first grafting date as it recorded 2.67 and $2.70 \%$, respectively, while the control treatment for organic and bio-fertilizers for the first and second grafting dates had the lowest percentage as it recorded 1.39 and $1.25 \%$, respectively.

With regard to the effect of the interaction between chemical fertilization (NPK) and organic and bio- fertilizers, it was found that the addition of the 5 and $10 \mathrm{~g}$ concentrations of Potasiomag fertilizer $+30 \mathrm{~g}$ of NPK fertilizer gave the highest percentage of potassium in the leaves and was significantly superior to other treatments, especially the control treatment of chemical, organic and bio-fertilizers, which gave the lowest values to this one.

As for the effect of the interaction among the dates of grafting, chemical fertilization (NPK) and organic and bio- fertilizers, it was clear that the control treatment of NPK fertilizer $+10 \mathrm{~g}$ of Potasiomag fertilizer for grafted seedlings at the first grafting date, it achieved the highest significant percentage of potassium in the leaves as it reached $2.80 \%$ compared to other treatments, especially the control treatment of organic and bio-fertilizers $+30 \mathrm{~g}$ of NPK fertilizer at the first and second grafting dates, which recorded the lowest percentages of this one.

\section{Sodium content in the leaves}

As shown in table (6), it was showed that the date of grafting did not significantly affect the percentage of sodium in the leaves, as there were no significant differences between the two dates for this one. Also, the addition of chemical fertilization from NPK did not significantly affect the percentage of sodium in the leaves, while the control treatment of the organic and bio-fertilizers achieved higher the percentage of sodium in the leaves, but it did not significantly outperform only the treatment of $10 \mathrm{~g}$ of Potasiomag fertilizer, which in turn did not differ significantly from other treatments, which had the lowest percentage to this one.

Table 6: Effect of date of grafting and chemical, organic and bio-fertilizers on the sodium content "\%" in the leaves of grafted orange seedlings

\begin{tabular}{|c|c|c|c|c|c|c|c|c|c|}
\hline \multirow[b]{2}{*}{$\begin{array}{c}\text { Date of } \\
\text { grafting }\end{array}$} & \multirow{2}{*}{$\begin{array}{c}\text { Chemical } \\
\text { fertilizers } \\
\text { NPK }\end{array}$} & \multicolumn{7}{|c|}{ Organic and bio-fertilizers } & \multirow[b]{2}{*}{$\begin{array}{l}\text { Date X } \\
\text { NPK }\end{array}$} \\
\hline & & $\begin{array}{c}\text { Control } \\
\text { Zero }\end{array}$ & $\begin{array}{c}\text { Biogen } \\
3 \mathrm{~g} .\end{array}$ & $\begin{array}{l}\text { Bioge } \\
\text { n } 6 \text { g. }\end{array}$ & $\begin{array}{c}\text { Potasiomag } \\
5 \mathrm{~g} .\end{array}$ & $\begin{array}{c}\text { Potasiomag } \\
10 \mathrm{~g} .\end{array}$ & $\begin{array}{c}\text { Fulzyme } \\
\text { 1g. }\end{array}$ & $\begin{array}{c}\text { Nutrigreen } \\
6 \mathrm{~m} / \mathrm{L} \text {. }\end{array}$ & \\
\hline \multirow{2}{*}{$\begin{array}{l}\text { First date } \\
2 / 4\end{array}$} & Zero & $\begin{array}{c}0.020 \\
\mathrm{a}\end{array}$ & $\begin{array}{c}0.018 \\
\mathrm{a}\end{array}$ & $\begin{array}{c}0.018 \\
\mathrm{a}\end{array}$ & $\begin{array}{c}0.022 \\
\mathrm{a}\end{array}$ & $\begin{array}{c}0.017 \\
\mathrm{a}\end{array}$ & $\begin{array}{c}0.015 \\
\mathrm{a}\end{array}$ & $\begin{array}{c}0.018 \\
\mathrm{a}\end{array}$ & $0.018 \mathrm{a}$ \\
\hline & $30 \mathrm{~g}$. & $\begin{array}{c}0.026 \\
\mathrm{a} \\
\end{array}$ & $\begin{array}{c}0.014 \\
\mathrm{a} \\
\end{array}$ & $\begin{array}{c}0.018 \\
\mathrm{a} \\
\end{array}$ & $\begin{array}{c}0.016 \\
\mathrm{a} \\
\end{array}$ & $\begin{array}{c}0.017 \\
\mathrm{a} \\
\end{array}$ & $\begin{array}{c}0.017 \\
\mathrm{a} \\
\end{array}$ & $\begin{array}{c}0.018 \\
\mathrm{a} \\
\end{array}$ & $0.018 \mathrm{a}$ \\
\hline \multirow{2}{*}{$\begin{array}{l}\text { Second } \\
\text { date } 17 / 4\end{array}$} & Zero & $\begin{array}{c}0.025 \\
a\end{array}$ & $\begin{array}{c}0.021 \\
\mathrm{a}\end{array}$ & $\begin{array}{c}0.026 \\
\mathrm{a}\end{array}$ & $\begin{array}{c}0.015 \\
a\end{array}$ & $\begin{array}{c}0.017 \\
a\end{array}$ & $\begin{array}{c}0.022 \\
\mathrm{a}\end{array}$ & $\begin{array}{c}0.019 \\
\mathrm{a}\end{array}$ & $0.021 \mathrm{a}$ \\
\hline & $30 \mathrm{~g}$. & $\begin{array}{c}0.021 \\
\mathrm{a} \\
\end{array}$ & $\begin{array}{c}0.019 \\
\mathrm{a} \\
\end{array}$ & $\begin{array}{c}0.019 \\
\mathrm{a} \\
\end{array}$ & $\begin{array}{c}0.021 \\
\mathrm{a} \\
\end{array}$ & $\begin{array}{c}0.017 \\
\mathrm{a} \\
\end{array}$ & $\begin{array}{c}0.018 \\
\mathrm{a} \\
\end{array}$ & $\begin{array}{c}0.018 \\
\mathrm{a} \\
\end{array}$ & $0.019 \mathrm{a}$ \\
\hline \multirow{2}{*}{$\begin{array}{l}\text { Date X } \\
\text { Bio and } \\
\text { organic } \\
\text { fertilizers }\end{array}$} & \multirow{2}{*}{$\begin{array}{l}\text { First } \\
\text { date } 2 / 4 \\
\text { Second } \\
\text { date } 17 / 4\end{array}$} & $\begin{array}{c}0.023 \\
\mathrm{a}\end{array}$ & $\begin{array}{c}0.016 \\
\mathrm{a}\end{array}$ & $\begin{array}{c}0.018 \\
\mathrm{a}\end{array}$ & $\begin{array}{c}0.019 \\
\mathrm{a}\end{array}$ & $\begin{array}{c}0.017 \\
\mathrm{a}\end{array}$ & $\begin{array}{c}0.016 \\
\mathrm{a}\end{array}$ & $\begin{array}{c}0.018 \\
\mathrm{a}\end{array}$ & \multirow{2}{*}{$\begin{array}{c}\begin{array}{c}\text { Date of } \\
\text { grafting }\end{array} \\
0.018 \mathrm{a} \\
0.020 \mathrm{a}\end{array}$} \\
\hline & & $\begin{array}{c}0.023 \\
\mathrm{a}\end{array}$ & $\begin{array}{c}0.020 \\
\mathrm{a}\end{array}$ & $\begin{array}{c}0.023 \\
\mathrm{a}\end{array}$ & $\begin{array}{c}0.018 \\
\mathrm{a}\end{array}$ & $\begin{array}{c}0.017 \\
\mathrm{a}\end{array}$ & $\begin{array}{c}0.020 \\
\mathrm{a}\end{array}$ & $\begin{array}{c}0.018 \\
\mathrm{a}\end{array}$ & \\
\hline \multirow{2}{*}{$\begin{array}{l}\text { Chemical } \\
\text { fertilizers } \\
\mathrm{X} \text { bio ad } \\
\text { organic } \\
\text { fertilizers }\end{array}$} & Zero & $\begin{array}{c}0.023 \\
\mathrm{a}\end{array}$ & $\begin{array}{c}0.019 \\
\mathrm{a}\end{array}$ & $\begin{array}{c}0.022 \\
\mathrm{a}\end{array}$ & $\begin{array}{c}0.019 \\
\mathrm{a}\end{array}$ & $\begin{array}{c}0.017 \\
\mathrm{a}\end{array}$ & $\begin{array}{c}0.018 \\
\mathrm{a}\end{array}$ & $\begin{array}{c}0.018 \\
\mathrm{a}\end{array}$ & $\begin{array}{c}\begin{array}{c}\text { NPK } \\
\text { fertilizers }\end{array} \\
0.019 \mathrm{a}\end{array}$ \\
\hline & $30 \mathrm{~g}$. & $\begin{array}{c}0.023 \\
\mathrm{a} \\
\end{array}$ & $\begin{array}{c}0.017 \\
\mathrm{a} \\
\end{array}$ & $\begin{array}{c}0.019 \\
\mathrm{a} \\
\end{array}$ & $\begin{array}{c}0.018 \\
\mathrm{a} \\
\end{array}$ & $\begin{array}{c}0.017 \\
\mathrm{a} \\
\end{array}$ & $\begin{array}{c}0,017 \\
\mathrm{a} \\
\end{array}$ & $\begin{array}{c}0.018 \\
\mathrm{a} \\
\end{array}$ & $0.018 \mathrm{a}$ \\
\hline $\begin{array}{r}\text { Bio and } \\
\text { ferti }\end{array}$ & $\begin{array}{l}\text { ganic } \\
\text { ers }\end{array}$ & $\begin{array}{c}0.023 \\
\mathrm{a}\end{array}$ & $\begin{array}{c}0.018 \\
a b\end{array}$ & $\begin{array}{c}0.020 \\
\mathrm{ab}\end{array}$ & $\begin{array}{c}0.018 \\
a b\end{array}$ & $\begin{array}{c}0.017 \\
b\end{array}$ & $\begin{array}{c}0.018 \\
\mathrm{ab}\end{array}$ & $\begin{array}{c}0.018 \\
a b\end{array}$ & \\
\hline
\end{tabular}

*Mean averages followed by different letters indicate significant differences between them according to Duncan polynomial test at a level of $5 \%$. 
With regard to the effect of interaction between the dates of grafting and chemical fertilization (NPK), it was obvious that there was no significant effect between chemical fertilization (NPK) and the grafting dates of grafting seedlings on sodium content in the leaves.

As for the effect of interaction between the dates of grafting and the organic and bio-fertilizers, it was showed that there was no significant effect between organic and bio-fertilizers and the grafting dates of grafting seedlings on sodium content in the leaves.

With regard to the effect of the interaction between chemical fertilization (NPK) and organic and bio- fertilizers, it was found that there was no significant effect between chemical fertilization (NPK) and organic and bio- fertilizers of grafting seedlings on sodium content in the leaves.

As for the effect of the interaction among the dates of grafting, chemical fertilization (NPK) and organic and bio- fertilizers, it was clear that the results of triple interactions between the study factors were recorded similar to their individual and double interactions results with respect to sodium content in the leaves, as the results obtained showed that all of these interactions did not differ significantly from each other.

\section{Discussion}

The difference in the percentage of success of grafting according to the date of its procedure may be due to the environmental conditions affecting the adhesion of grafting wounds, especially temperatures and relative humidity, which are among the most important of these conditions (Muhammad et al., 2015), and the reason for the significant difference in the percentage of successful grafts according to the date of its procedure may explain as a result of the difference in the physiological status of the rootstock and the graft, as its different contents are encouraging and growth inhibitors (Erdogan, 2006), and the increase in the number of leaves at the time of the first grafting may be the result of an increase in the percentage of successful grafts and an increase in the opening of the lateral buds and an increase in the leaf area, which leads to an increase in efficiency the process of photosynthesis and the increase of its products used in the growth of grafted seedlings (Seletsu et al., 2011), in addition to the increase in the number of leaves may be the result of an increase in the formation of growth stimulators such as auxins, gibberellins and cytokines, which would increase the plant growth due to its important role in cell division and elongation and differentiation as well as the early opening of grafts and then obtain grafted seedlings in a short time, and the increase in the percentage of nitrogen in the leaves to grafted seedlings at the first date may be explained as a result of an increase in the leafy area and the efficiency of the roots in the absorption of nutrients, which leads to an increase in the efficiency of photosynthesis, which positively affects the absorption of $\mathrm{NH}_{4}$ due to an increase in the representation of ammonia within the plant and thus an increase in the percentage of nitrogen, in addition to increasing vital activities in the plant during the first date to graft seedlings and their direct impact on the characteristics of vegetative growth positively, and thus encouraged to increase the absorption of nitrogen and increase its percentage in the leaves.

The significant increase in percentage of successful grafts when adding bio-fertilizers can be explained as a result of the importance of these fertilizers in providing different nutrients and hormones for treated seedlings compared to untreated seedlings, as bio-fertilizers increase the efficiency of photosynthesis and make nutrients needed to open and grow buds of the grafts and the increase of their products used in the growth of grafted seedlings such as carbohydrates and proteins and thus increase the percentage of successful grafts, in addition to its ability to produce a number of growth regulators such as auxins, gibberellins and cytokines, which would increase plant growth due to its important role in cell division, elongation and differentiation as well as early in the grafts open and then get grafted seedlings in a short time (Bhat et al., 2019). As for the significant superiority of most of the studied vegetative growth characteristics as a result of adding bio-fertilizers, especially "Potasiomag" fertilizer, it may be explained by the role of these fertilizers in improving the growth of seedlings by improving the nutritional state of plant growth as a result of the increased efficiency of photosynthesis and the accumulation of carbohydrates in seedlings, which is reflected positively in stimulating lateral buds and increasing the number of branches as well as the production of some growth hormones such as auxins, cytokines and gibberellins, which in turn makes to improve plant growth by increasing and stimulating the growth of developing peaks and increasing elongation and it also increases the ability of the plant to absorb nutrients and water from the soil solution surrounding the roots of the plant and thus this is reflected positively in improving the characteristics of vegetative 
growth (Salama et al., 2017). The significant superiority of adding potassium fertilizer to increasing the content of leaves of grafted seedlings of nitrogen and potassium may be attributed to the role of Bacillus circulans in fixing the nitrogen from atmosphere by converting the nitrogen gas $\mathrm{N}_{2}$ into ammonia or by converting nitrogen from the ammonia image to nitrate so that it becomes available to the plant and all of these organisms possess the Nitrogenase enzyme which fixes the nitrogen which in turn synthesizes the amino acids and proteins important in building the vital parts of the plant (Sharma et al. 2019), in addition to that Bacillus circulans have the ability to convert potassium from the insoluble form to a soluble form to be available for absorption by the plant, then increasing its absorption from the roots, its transmission and its representation within the plant, so the leaf content of the element increases (Bhat et al., 2019), and the bio-fertilizer "Potasiomag" had the highest significant value to the available potassium in the soil due to the role of Bacillus circulans in increasing of potassium in the soil through the production of some plant growth regulators and thus the development of root system growth and then increased absorption of potassium, as it has the ability to dissolve potassium and make it available to plants in the rhizosphere and thus increase the vital effectiveness of absorption (Parmar and Sindhu, 2013).

\section{References}

Bhat, M.A., R. Rasool and S. Ramzan, 2019. Plant Growth Promoting Rhizobacteria (PGPR) for Sustainable and Eco-Friendly Agriculture. Acta Scientific Agriculture 3(1): 23-25.

Bremner, J.M. and C.S. Mulvaney, 1982. Nitrogen total. (595-624).In. A. L. Page (ed.) Methods of soil analysis, Agron. No.9 Part 2.Chemical and microbiological properties $2^{\text {nd }}$ ed.,Am.Soc.Agron.Madison,WI, USA.

Chaudhary, M., 2000. Fruit crop. In MN Malik (Ed), Horticulture. Biotech Books, Delhi (India), 442443.

Duncan, D. B., 1955. Multiple range and multiple F tests. Biometrics. 11: 1-42.

Erdogan, V., 2006. Effect of hot callusing cable on graft success in walnut (Juglans regia) propagation: nursery results. Indian Journal of Agricultural Sciences, 76(9): 544-556.

Hartmann, H.T., D.E. Kester; F.T. Davies and R.L. Geneve, 2002. Plant propagation, principles and practices. 7 edition Prentice upper saddle river-Hall, Iac, New Jersey.

Hassan, H. S., A. Laila, F. Hagag, M. Abou Rawash, H. El-Wakeel and A. Abdel-Galel, 2010. Response of Klamata Olive young trees to mineral, organic Nitrogen fertilization and some other treatments. Nature and Science, 8(11): $59-65$.

Horneck, D.A. and D. Hanson, 1998. Determination of potassium and sodium by flame emission spectrophotometry. 153-155. In: Kalra, Y. P. (ed.). Handbook of Reference Methods for Plant Analysis. Soil and Plant Analysis Council, Inc. CRC Press. FL. USA. 287.

Khan, I.A., 2007. Citrus genetics, breeding and biotechnology. CAB International, UK. : 370.

Mohamed, S.A., and O.N. Massoud, 2017. Impact of Inoculation with Mycorrhiza and Azotobacter under Different N and P Rates on Growth, Nutrient status, Yield and Some Soil Characteristics of Washington Navel Orange Trees . Middle East Journal of Agriculture Research. 6 (3): 617 638.

Muhammad, R., M.N. Khan, S. Ahmad, M.A. Bashir and M. Ahmad, 2015. Grafting time affects scion growth in Sweet Orange under arid Environment. Pak. j. life soc. Sci., 13(1): 58-61.

Obreza, T.A., M . Zekri and E. W. hanlon, 2008. Soil and Leaf Tissue Testing. In: Nutrition of florida citrus trees, Obreza , T. A. and K . T. morgan (eds) $2^{\text {nd }}$ eds . Florida Cooperative Extension Service, Institute of Food and Agricultural Sciences, Univ . Florida .: 24-32 .

Page, A.L., R.H. Miller and D.R. Keeny, 1982. Methods of soil analysis part (2) $2^{\text {nd }}$ (ed). Agronomy 9 . Amer. Soc. Agron. Madison Wisconsin .

Parmar, P., and S. Sindhu, 2013. Potassium solubilisation by rhizosphere bacteria: Influence of nutritional and environmental conditions. Journal of Microbiology Research, 3(1): 25-31.

Salama, M.I., R.A. Sayed, A.R. El-Shereif and M.A. Mankolah, 2017. Response of Washington Navel Orange trees to some soil amendments and foliar application of $\mathrm{GA}_{3}$ under clay soil conditions. J. Sus. Agric. Sci., 43(1):39-54.

SAS. 2001. SAS/ STAT Users Guide for personal computers, SAS Institute Inc, Cary, N. C. USA. 
Seletsu, S.P., K. Paul and K. Thangjam, 2011. Effect of time and species on bud union and survivability in Citrus under Allahabad condition. Journal of Crop and Weed, 7(1): 89-93.

Sharma, K., S. Sharma and S.R. Prasad, 2019. PGPR: Renewable Tool for Sustainable Agriculture. International Journal of Current Microbiology and Applied Sciences. 8(1): 525-530. 